\title{
МОДЕРНИЗАЦИЯ ИНСТИТУТА ПРАВОТВОРЧЕСКОЙ ИНИЦИАТИВЫ ГРАЖДАН: РОССИЙСКИЙ И ЗАРУБЕЖНЫЙ ОПЫТ
}

\begin{abstract}
Аннотация: В статье отмечается, что одной из форм общественных инициатив является правотворческая инициатива населения. Анализируется отечественная и зарубежная практика участия населения в правотворческом прочессе. В статье рассматриваются перспективы более активного участия населения в правотворчестве посредством электронных ресурсов, в частности сети Интернет, формулируются предложения по совершенствованию механизма реализации правотворческой инициативы как общественной инициативы граждан. Приводятся примеры и дается анализ развития данной формы прямого волеизъявления граждан в Российской Федерации. Методологией данного исследования служит общенаучный диалектический метод познания и вытекающие из него частно-научные методы: системно-структурный, конкретно-сочиилогический, технико-юридический и метод сравнительного анализа. Основными выводами проведенного исследования являются выводы о необходимости совершенствовать законодательство о правотворческой инициативе, поскольку отлаженньй механизм правотворческой инициативы дает гражданам возможность непосредственно осуществлять власть, создавая правовые акты, в соответствии с которыми они живут. При этом авторский вклад в исследование заключается в том, что выявлены противоречия между правотворческой инициативой, закрепленной в Ф3-131 "Об общих принципах организации местного самоуправления в РФ" и Указом Президента РФ №183, дан анализ зарубежного опыта правотворческой инициативы, сделаны предложения по севершенствованию законодательства.
\end{abstract}

Ключевые слова: Общцественные инициативы, правотворческая инициатива, электронные ресурсы, местное самоуправление, прямое волеизъявление граждан, правотворческая деятельность, гражданская активность, Интернет ресурсы, зарубежный опыт, демократия.

Abstract: In this research the author notes that one of the forms of public initiatives is the legislative initiative of the populace. The author analyzes Russian and foreign practice of civic participation in the legislative process. The article examines the prospects for a more active participation of population in the legislation through electronic resources, and presents proposals for improving the mechanism of the realization of legislative initiative as a public initiative of the citizens. Examples are given along with the analysis of the development of this form of direct exercise of will of the citizens of the Russian Federation. Among the main conclusions is the acknowledgement of the need to improve the legislation on lawmaking initiative, since a fine-tuned mechanism of legislative initiative gives the citizens an ability to directly exercise power, creating legal acts that correspond with their way of life. The author's contribution to the research consists in detection of contradictions between the legislative initiatives under the Federal Law No. 131-FZ "On universal principles of organization of local self-governance in the Russian Federation" and the Executive Order No. 183-RF of the President of the Russian Federation. The author analyzes foreign experience in the area of legislative initiative, and makes proposals on improvements to the Russian legislation.

Keywords: Civic activity, lawmaking, direct expression of will, local self-governance, electronic resources, legislative initiative, public initiatives, Internet resources, foreign experience, democracy.

\section{Статья выполнена при поддержке РГНФ по проекту номер 15-53-00023 «Развитие института общественных инициатив граждан в Российской Федерации и за рубежсм (Франция, Великобритания, США)».}

П равотворческая инициатива граждан - форма участия граждан в осуществлении местного самоуправления, реализующая право населения на правотворческую инициативу в вопросах местного значения, которая осуществляется путем внесения обязательных для рассмотрения проектов правовых актов по вопросам местного значения в органы местного самоуправления) [1].
Волеизъявление граждан и их правотворческая инициатива не означают обязательного принятия органом местного самоуправления инициированного ими правового акта. Однако проект муниципального правового акта, внесенный в порядке реализации правотворческой инициативы граждан, подлежит обязательному рассмотрению органом местного самоуправления 
или должностным лицом местного самоуправления, к компетенции которых относится принятие соответствующего акта. Представителям инициативной группы граждан должна быть обеспечена возможность изложения своей позиции при рассмотрении указанного проекта. В случае, если принятие муниципального правового акта, проект которого внесен в порядке реализации правотворческой инициативы граждан, относится к компетенции коллегиального органа местного самоуправления, указанный проект должен быть рассмотрен на открытом заседании данного органа.

Отказ в реализации правотворческой инициативы граждан должен быть мотивированным. В этом случае он не влечет за собой никаких юридических последствий. Любое мотивированное решение должно быть официально в письменной форме доведено до сведения внесшей его инициативной группы граждан. При этом, возможность повторного внесения проекта правового акта в Федеральном законе от 6 октября 2003 г. «Об общих принципах организации местного самоуправления в Российской Федерации» не предусмотрена. В связи с этим, представляется необходимым внести изменения в часть 2 статьи 26 указанного Федерального закона указав, что если в принятии проекта правового акта инициативной группе было отказано, то это не является препятствием для повторного внесения инициативной группой проекта правового акта в порядке реализации правотворческой инициативы при условии устранения нарушений, вызвавших отказ [2].

По сравнению с институтами прямой демократии на федеральном или региональном уровне удельный вес решений вопросов местного значения путем прямого волеизъявления населением муниципальных образований традиционно выше. Это связано с тем, что реализация и применение на местном уровне институтов прямой демократии напрямую вытекает из требований ч. 2 ст. 130 Конституции РФ. Смысл данных конституционных положений заключается в усилении демократизации на местном уровне, более широком участии населения муниципальных образований в решении вопросов местного значения. Как справедливо подчеркивается в юридической литературе, «в принципиальном плане масштаб, удельный вес решения вопросов местного значения путем прямого волеизъявления членов территориального коллектива должны быть выше, чем такое же решение вопросов на государственном уровне. В этом, в частности и в особенности, проявляется «корневой» характер муниципальной власти, ее институциональная характеристика как власти, максимально приближенной к населению и в определенной мере сливающейся с ним»[3].

Подобный подход характерен и для большинства зарубежных стран. Например, во Франции не предусмотрена законодательная инициатива граждан на уровне государства, однако на местном уровне закреплено право граждан на правотворческую инициативу.

Существуют две возможности осуществления инициативы: народная правотворческая инициатива (initiative populaire) и проведение консультаций с местным сообществом. В обоих случаях, однако, только представительный орган (местная ассамблея) правомочен устанавливать принципы и организовывать условия проведения инициативы. В его решении должно быть прямо указано, что данная инициатива является лишь запросом на мнение населения, а также должен быть установлен день проведения голосования по вопросам инициативы.

В соответствии со статьей L. 1112-5 Кодекса о местных сообществах [4]: «избиратели местной власти имеют право по своей инициативе осуществлять консультации касательно решений, которые власти этой общины намерены принять в пределах своей компетенции. Количество человек для консультации может быть ограничено частью избирателей, а также вопросами, связанными с этой частью сообщества». Консультации могут проводиться в рамках любой юрисдикции совета либо местной исполнительной власти, включая мэра, но только в тех случаях, когда вопросы находятся в компетенции данного муниципального образования.

Что касается народной правотворческой инициативы, то во французском законодательстве делается различие между инициативой в одной коммуне и межмуниципальной инициативой. В первом случае 1/5 часть зарегистрированных избирателей должна подписать запрос на инициативу, а во втором - необходимо собрать подписи 1/10 части зарегистрированных избирателей из вовлеченных в инициативу департаментов и регионов. В год избиратель может подписать только один запрос на организацию инициативы по отношению к той же местной власти.

По-прежнему остается спорным вопрос, обязаны ли ассамблеи (представительные органы) присоединиться к просьбе избирателей. Некоторые авторы [5] считают на основании ранее принятых решений, что если местное сообщество (те избиратели) выступает с инициативой, то власть обязана ее поддержать пусть не безоговорочным принятием данной инициативы, но хотя бы рассмотрением на повестке дня поднятых вопросов. Указанная позиция соответствует решению 
DOI: $10.7256 / 1811-9018.2015 .11 .16609$

При цитировании этой статьи сноска на dоі обязательна

\section{Право и политика 11 (191) 2015}

Административного трибунала Рейна [6], подтвержденному решением Государственного Совета[7], но в итоге отмененное постановлением административного апелляционного суда г. Парижа [8], который в своем решении подтвердил прежнюю позицию властей и указал, что поданные инициативы не обязательны к включению в повестку дня ассамблеи, и вопрос о включении их в повестку дня вправе разрешить лишь совещательная комиссия ассамблеи.

Другие авторы [9] утверждают, что закрепление в законе положения об исключительных полномочиях ассамблей принимать решение о возможности организации консультаций и народных инициатив, дает последним дискреционные полномочия, которые в конечном итоге могут привести к отрицанию эффективности процесса народной правотворческой инициативы.

Таким образом, мы видим, что не только в Российской Федерации правотворческая инициатива носит рекомендательный характер. Органы власти даже на местном уровне не придают народной инициативе обязательного статуса.

Говоря о практической реализации правотворческой инициативы, нельзя не сказать о быстрорастущих темпах развития научно-технического прогресса, которые, на наш взгляд, оправданно диктуют «новые правила игры», в частности, предоставляя реальную возможность, а порой и необходимость эффективного функционирования института правотворческой инициативы в глобальной информационной сети «Интернет». В частности, об этом высказывался В.В. Путин в рамках своей статьи «Демократия и качество государства» [10], где он подчеркивал, что мы должны своевременно реагировать на запросы граждан Российской Федерации, которые всё более усложняются, а в условиях «информационного века» приобретают качественно новые черты.

В глобальной информационной сети «Интернет» имеются зарубежные платформы для реализации права граждан на инициативы - в первую очередь американский ресурс «We the People» [11] и британский «E-petitions» [12]. Данные peсурсы, на наш взгляд, являются ключевыми инструментами демократии в современном мире, которые позволяют гражданам страны обратиться к своему правительству напрямую. Например, на ресурсе «We the People» каждый американец, достигший 13-летнего возраста, может поддержать близкую ему инициативу или стать автором новой петиции, собрав необходимое количество подписей. На данный момент на сайте представлено свыше 160 петиций. Самая популярная требует при- знания «Westboro Baptist Church» [13] экстремистской организацией. Но больший интерес вызывает предложение к Конгрессу об издании закона «Дмитрия Долматова» [14] с избранием меры наказания всем голландцам, виновным в смерти русского оппозиционера. К слову говоря, под это петицией уже подписалось более 100 тысяч человек.

В настоящее время Указом Президента Российской Федерации утверждены Правила рассмотрения общественных инициатив, направленных гражданами Российской Федерации с использованием Интернетресурса «Российская общественная инициатива» [15]. При этом, рассмотрению в соответствии с указанными Правилами подлежат направленные гражданами Российской Федерации:

общественные инициативы, реализуемые на региональном и муниципальном уровнях, - с 1 ноября 2013 г.

Общественными инициативами считаются предложения граждан Российской Федерации по вопросам социально-экономического развития страны, совершенствования государственного и муниципального управления, направленные с использованием Интернетресурса «Российская общественная инициатива» (далее - интернет-ресурс) и отвечающие установленным требованиям.

Направлять общественные инициативы с использованием Интернет-ресурса и голосовать за них могут граждане РФ, достигшие возраста 18 лет, зарегистрированные в федеральной государственной информационной системе «Единая система идентификации и аутентификации в инфраструктуре, обеспечивающей информационно-технологическое взаимодействие информационных систем, используемых для предоставления государственных и муниципальных услуг в электронной форме» (ЕСИА).

Размещению общественной инициативы на Интернет-ресурсе предшествует обязательная предварительная экспертиза, проводимая Фондом развития информационной демократии и гражданского общества «Фонд информационной демократии». Срок проведения предварительной экспертизы не должен превышать два месяца.

Размещенная на Интернет-ресурсе общественная инициатива должна получить необходимую поддержку в ходе голосования с использованием Интернетресурса. Поддержанной считается инициатива, которая в течение одного года после ее размещения на Интернет-ресурсе получила:

не менее 5 процентов голосов граждан, постоянно проживающих на территории соответствующего муни- 
DOI: 10.7256/1811-9018.2015.11.16609

При цитировании этой статьи сноска на dоі обязательна

Человек и государство

ципального образования, - в поддержку инициативы муниципального уровня.

Далее общественная инициатива, получившая в ходе голосования необходимую поддержку, направляется в электронном виде уполномоченной некоммерческой организацией в экспертную рабочую группу соответствующего уровня (федерального, регионального или муниципального) для проведения экспертизы и принятия решения о целесообразности разработки проекта соответствующего нормативного правового акта и (или) об иных мерах по реализации данной инициативы. Информация о направлении общественной инициативы в экспертную рабочую группу соответствующего уровня и принятых ею решениях размещается на Интернет-ресурсе.

Состав экспертной рабочей группы муниципального уровня определяется органами местного самоуправления и включает представителей этих органов, депутатов представительных органов муниципальных образований, представителей муниципальных учреждений, бизнес-сообщества и общественных объединений.

Таким образом, мы видим, что Указ Президента Российской Федерации №183 отвечает требованиям современной действительности. Однако, отдельные положения данного Указа №183 не соответствуют некоторым статьям Федерального закона №131 «Об общих принципах организации местного самоуправления» [16].

Во-первых, в статье 26 Федерального закона №131 «Об общих принципах организации местного самоуправления» закреплено, что: «С правотворческой инициативой может выступить инициативная группа граждан. Минимальная численность инициативной группы граждан не может превышать 3 процента от числа жителей муниципального образования, обладающих избирательным правом», при этом нормативным правовым актом представительного органа муниципального образования может быть установлена даже меньшая минимальная численность инициативной группы.

При этом в Указе Президента Российской Федерации №183 планка процента голосов граждан в поддержку инициативы повышена до 5 процентов, а инициатива может быть выдвинута и одним человеком. На наш взгляд, данное повышение планки процентов голосов вытекает из того, что глобальной сетью «Интернет» пользуется большее количество человек и, соответственно, собрать нужное количество подписей будет гораздо проще. При этом сама возможность выдвижения инициативы одним жителем является достаточно демократичной, т.к. позволяет каждому гражданину участвовать в жизни муниципалитета, не создавая при этом инициативных групп.

Во-вторых, согласно Указу Президента РФ №183, высказываться в поддержку инициативы могут граждане, постоянно проживающие на территории муниципального образования. В статье 26 Федерального закона №131 закреплено, что поддержать инициативу могут жители муниципального образования. В российском законодательстве [17] под местом жительства понимается место, в котором гражданин постоянно или преимущественно проживает в качестве собственника, по договору найма (поднайма), договору аренды либо на иных основаниях, предусмотренных законодательством Российской Федерации. Местом жительства гражданина, относящегося к коренному малочисленному народу Российской Федерации, ведущего кочевой и (или) полукочевой образ жизни и не имеющего места, где он постоянно или преимущественно проживает, может быть признано одно из поселений, находящихся в муниципальном районе, в границах которого проходят маршруты кочевий данного гражданина.

Следовательно, Указ Президента РФ №183 сужает круг граждан, которые могут поддержать инициативу на местном уровне, предоставляя указанное право только тем, кто постоянно проживает в муниципальном образовании.

В этой связи видится необходимость в приведении именно статьи 26 Федерального закона №131 «Об общих принципах организации местного самоуправления» в соответствии с положениями Указа Президента, поскольку Указ Президента отвечает современным реалиям, регулирует порядок реализации общественных инициатив (в том числе правотворческой инициативы) посредством сети «Интернет», что является новацией законодательства.

Таким образом, необходимо совершенствовать законодательство о правотворческой инициативе, поскольку реализация правотворческой инициативы дает реальную возможность любым социальным группам населения и отдельным гражданам принимать непосредственное участие в решении местных вопросов гражданам, а также позволяет соответствующим органам общественного самоуправления принимать решения с учетом мнения и интересов большинства населения. Отлаженный механизм правотворческой инициативы дает гражданам возможность непосредственно осуществлять власть, создавая правовые акты, в соответствии с которыми они живут, что способствует развитию гражданского общества и совершенствованию правовой системы страны. 
DOI: $10.7256 / 1811-9018.2015 .11 .16609$

При цитировании этой статьи сноска на доі обязательна

\section{Право и политика $11(191) \cdot 2015$}

\section{Библиография:}

1. Авакьян С.А. Муниципальное право России. - М.: Проспект, 2011

2. Бычкова, Е.И. Реализация правотворческой инициативы граждан как форма участия населения в осуществлении местного самоуправления: автореф. дис. .канд. юрид. наук / Е.И. Бычкова.

3. Васильев В.И. Законодательная основа муниципальной реформы. М., 2005

4. Code général des collectivités territoriales/ Электронный ресурс. Режим доступа: http://www.legifrance.gouv.fr/affichCode. do?cidTexte $=$ LEGITEXT000006070633

5. D. Lanbeck L'information des assemblées délibérantes locales. Enjeux et difficultés : AJDA 2003, p. 1138; Muller-Quoy. Le droit des assemblées locales : LGDJ, coll. "Systèmes", 2001

6. Tribunal Administrative, Rennes, 11 sept. 2003, Assoc. défense site Lancieux: Dr. adm. 2004, comm. 3

7. Conseil d'Etat, 1er déc. 2003, n ${ }^{\circ}$ 259684, Cne Lancieux

8. Cour administrative d'appel Paris, 22 févr. 2005, Assoc. Les amis de la terre du val d'Ysieux c/ Cne Luzarches : AJDA 2005 , p. 1052

9. L'Harmattan. Les mutations de la démocratie locale, 2011

10. Демократия и качество государства//В.В. Путин/Электронный pecypc/putin2012.ru/\#article-4

11. Интернет-ресурс «We the Pеople»//Электронный ресурс/ petitions.whitehouse.gov/

12. Интернет-ресурс «E-Petitions»//Электронный ресурc/ epetitions.direct.gov.uk/

13. Интернет-ресурс «Официальный сайт «Westboro Baptist Church»//Электронный pecypc/ godhatesfags.com/

14. Интернет-ресурс «Российская газета»//Электронный ресурс/ rg.ru/2013/02/03/dolmatov-site.html

15. Указ Президента РФ от 04.03.2013 № 183 «О рассмотрении общественных инициатив, направленных гражданами Российской Федерации с использованием интернет-ресурса «Российская общественная инициатива»//Электронный pecypc/ http://www.pravo.gov.ru

16. Федеральный закон от 06.10.2003 N 131-Ф3 «Об общих принципах организации местного самоуправления в Российской Федерации»//Собрание законодательства Российской Федерации.-2003.-№40-Ст. 3822

17. Закон РФ от 25.06.1993г. №5242-1 «О праве граждан Российской Федерации на свободу передвижения, выбор места пребывания и жительства в пределах Российской Федерации»//Российская газета. - 1993. - №152

18. Тюлегенов А.Э. Муниципальная демократия как механизм реализации местного самоуправления // Административное и муниципальное право. - 2014. - 7. - С. 689 - 695. DOI: 10.7256/1999-2807.2014.7.12241.

\section{References (transliterated):}

1. Avak'yan S.A. Munitsipal'noe pravo Rossii. - M.: Prospekt, 2011

2. Bychkova, E.I. Realizatsiya pravotvorcheskoi initsiativy grazhdan kak forma uchastiya naseleniya v osushchestvlenii mestnogo samoupravleniya: avtoref. dis. .kand. yurid. nauk / E.I. Bychkova.

3. Vasil'ev V.I. Zakonodatel'naya osnova munitsipal'noi reformy. M., 2005

4. D. Lanbeck L'information des assemblées délibérantes locales. Enjeux et difficultés : AJDA 2003, p. 1138; Muller-Quoy. Le droit des assemblées locales : LGDJ, coll. "Systèmes", 2001

5. L'Harmattan. Les mutations de la démocratie locale, 2011

6. Tyulegenov A.E. Munitsipal'naya demokratiya kak mekhanizm realizatsii mestnogo samoupravleniya // Administrativnoe i munitsipal'noe pravo. - 2014. - 7. - C. 689 - 695. DOI: 10.7256/1999-2807.2014.7.12241. 